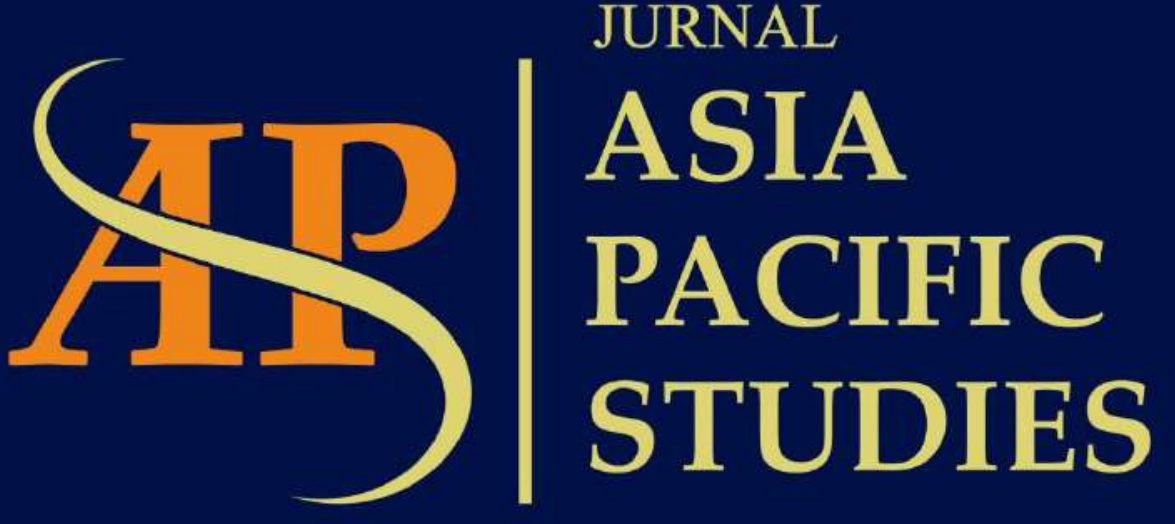

Journal of International Relations Study Program Faculty of Social and Political Sciences Universitas Kristen Indonesia

Volume 3 | Number 2 | July - December 2019 


\title{
POLITIK SEKURITISASI KONTRA-TERORISME GLOBAL AUSTRALIA PASCA 9/11 HINGGA TERPILIHNYA KEMBALI PERDANA MENTERI HOWARD
}

\author{
Rahmat Ansari \\ Magister Hubungan Internasional, Fakultas Ilmu Sosial dan Ilmu Politik, Universitas Indonesia, Gedung \\ Nusantara II Lt. 2 FISIP UI, Depok, 16424, Indonesia. \\ Email: rahmatansariariq@gmail.com
}

\begin{abstract}
Abstact
Prime Minister Howard as a dominant actor in Australia's securitization process of counterterrorism post 9/11. The securitization then resulting activation of Article IV of ANZUS alliance treaty. This study utilizes securitization framework through speech act conducted by Prime Minister Howard. It argues that speech act carried out by Prime Minister Howard in some occasions by speech in Australian Embassy in The United States, at the cabinet meetings, and parliament hearings. As the result, the process of securitization obtained a legitimacy for extraordinary measures in form of military support on global terrorisme eradication campaign. This study using kualtitative methods with data limits since 9/11 and Prime Minister Howard reelection in 2001 .
\end{abstract}

Keywords: Securitization, Terrorism, ANZUS, Afghanistan Invasion.

\begin{abstract}
Abstrak
Perdana Menteri Howard sebagai aktor dominan dalam proses sekuritisasi kontra-terorisme Australia pasca 9/11. Sekuritisasi tersebut kemudian menghasilkan aktifasi Pasal IV perjanjian aliansi ANZUS. Kajian ini menggunakan kerangka sekurtisasi melalui speech act yang dilakukan oleh Perdana Menteri Howard. Kajian ini berpendapat bahwa proses sekuritisasi melalui speech act yang dilakukan dalam beberapa kesempatan pidatonya di Kedutaan Australia di Amerika Serikat, pada rapat kabinet khusus dan pada debat bersama parlemen . Pada akhirnya berhasil memperoleh legitimasi untuk dilakukannya tindakan luar biasa atau extraordinary measures dalam bentuk dukungan militer pada invasi Afghanistan untuk pemberantasan jaringan terorisme global. Kajian dibahas menggunakan metode kualitatif yang membatasi data sejak 9/11 hingga terpilihnya kembali Perdana Menteri Howard pada pemilu 2001.
\end{abstract}

Kata Kunci: Sekuritisasi, Terorisme, ANZUS, Invasi Afghanistan.

\section{Pendahuluan}

Serangan terorisme pada 11 September 2001 atau 9/11 yang terjadi di Amerika Serikat merupakan serangan terorisme terparah sejak berakhirnya perang dunia II. Organisasi ekstrimis al-Qaida dianggap sebagai pihak yang bertanggung jawab atas serangan yang menewaskan hingga lebih dari 3.000 jiwa yang berasal dari 85 negara, sepuluh diantaranya merupakan warga negara Australia. Perdana Menteri Australia saat itu, John Howard, dengan dukungan Parlemen Australia merespon dengan mengumumkan komitmen Australia untuk melakukan "Perang terhadap Terorisme" yang secara resmi disampaikan pada 17 September 2001. Sejak saat itu, 
ncaman terorisme berbasis ekstrimis Islam menjadi isu serius oleh pemerintah Australia terutama pada masa pemerintahan Perdana Menteri Howard.

Ancaman terorisme ekstrimis Islam semakin serius terhadap kepentingan Australia di luar negeri terutama di wilayah Timur Tengah dan Asia Tenggara. Australia bersama dengan Amerika Serikat menempatkan posisi Timur Tengah dan Asia Tenggara sebagai wilayah rawan berkembangnnya aksi terorisme. Terlebih, kemunculan aktifitas organisasi-organisasi terduga teroris yang meningkat diwilayah tersebut. Peningkatan aktifitas jaringan terorisme Jemaah Islamiyah yang memiliki hubungan dengan al-Qaida di beberapa daerah di Asia Tenggara meningkatkan potensi ancaman Australia yang selama bertahun-tahun berada pada spektrum ancaman sangat rendah hingga rendah. Laporan pertanggung jawaban Australian Security Intelligence Organisation (ASIO) menunjukkan tingkatan operasi intelijen pada tahun 20012002 meningkat menjadi rendah hingga sedang dari yang sebelumnya sangat rendah bahkan tidak tercatat sebagai ancaman (ASIO Report to Parliament 2001-2002 2002)

Sebelum terjadinya serangan 9/11 hukum Australia tidak ada yang secara spesifik mengatur tentang tindakan terorisme. Dalam formulasi legislasi pertama tindakan antiterorisme, Parlemen Federal Australia membahas setidaknya lima Rancangan UndangUndang (RUU) hingga 12 Maret 2002 saja, kurang dari enam bulan sejak terjadinya peristiwa 9/11. Dengan demikian, inisiatif Australia tersebut menimbulkan banyak pertanyaan penting karena dianggap berlebihan. Terlebih spektrum ancaman terorisme dalam negeri cenderung rendah. Terlebih, dalam perspektif legal, ketentuan yang diatur memiliki kecenderungan untuk bertentangan dengan HAM dan hak sipil yang bisa menjadi bumerang bagi hubungan masyarakat dan pemerintah (Michaelsen 2006).

Inisiatif Australia terkait kontra-terorisme dengan memberikan dukungan terhadap invasi di Afghanistan menarik untuk dikaji lebih dalam, terutama berkaitan dengan proses sekuritisasi yang dilakukan untuk menjustifikasi inisiatif yang tinggi sejak serangan 9/11. Lebih lanjut, keberhasilan Perdana Menteri Howard dalam melakukan politisasi isu terorisme global ditunjukkan secara signifikan yang bahkan membuat Perdana Menteri Howard kembali menjabat dengan memenangkan pemilu 2001 dan 2004. Fokus utama dari kajian ini berusaha menganalisa bangunan konseptual atas inisiatif yang dilakukan oleh Pemerintah Australia dalam melihat ancaman terorisme. Kajian ini berpendapat bahwa Perdana Menteri Howard melakukan sekuritisasi melalui speech act terhadap ancaman terorisme dengan berbagai komponen dan proses baik dalam tingkatan domestik yang berimplikasi pada kebijakan luar negeri yang diambil. Inisiatif Australia untuk melakukan kontra-terorisme global dengan memberikan dukungan terhadap invasi ke Afghanistan pada tahun 2001 tanpa landasan hukum domestik yang kuat sebagai bentuk tindakan luar biasa (extraordinary measure) untuk memitigasi ancaman. Lebih lanjut, konsensus secara politik dalam negeri Australia terkait isu terorisme menjadi terwujud. Pada akhirnya, hal ini dimanfaatkan sebagai kekuatan politik yang bahkan membuat terpilihnya kembali Perdana Menteri Howard pada pemilu tahun 2001 dan 2004. Secara kausalitas sederhana, terpilihnya kembali Perdana Menteri Howard dan tindakan luar biasa yang dilakukan di Afghanistan merupakan spektrum pemberian legitimasi atas sebuah politik sekuritisasi isu terorisme di Australia.

\section{Kajian Pustaka dan Kerangka Pemikiran}

Kajian terdahulu mengenai topik ini umumnya menggunakan dua sudut pandang, yaitu ideational dan material. Pendekatan ideational menilai posisi konseptual dan postur penting dari konstruksi identitas dan norma menjadi sangat krusial untuk memitigasi ancaman terorisme. Hingga saat ini, negara-negara disekitar Australia belum memiliki mekanisme praktikal yang dapat berjalan untuk merespon ancaman terorisme di kawasan. Identitas dari 
shared regional security community (Chau 2008), belum sepenuhnya mampu menjangkau persepsi ancaman terorisme ke negara-negara yang berada di kawasan Asia Tenggara dan Pasifik (Vaughn 2004). Meskipun demikian, Australia menghadapi tantangan yang cukup sulit untuk mengkonstruksikan ancaman dengan adanya konteks keagamaan dan kultural yang harus diperhatikan. Penting bagi Australia untuk membentuk sebuah konsep kebersamaan yang dapat menjadi pemicu untuk memitigasi ancaman secara bersama (Lyon 2003).

Secara material kajian terdahulu dapat dibedakan menjadi kajian internal dan eksternal. Kajian internal membahas dinamika yang terjadi dalam negara Australia melalui perspektif politik dan hukum. Kajian ini menunjukkan adanya respon yang tidak proporsional oleh pemerintahan Perdana Menteri Howard dalam ruang lingkup HAM yang berkaitan dengan ancaman terorisme. Kajian internal membahas persepsi ancaman melalui pandangan historis hingga praktis dari berlakunya legislasi dan implementasinya. Kajian ini menilai respon legislatif Australia yang tiba-tiba, luar biasa dan meningkat terhadap terorisme hanya menunjukkan adanya evolusi tindakan politik dan hukum yang ambigu dan kontingen di dalam sistem (Crowley \& Larsen 2015). Dalam jangka panjang, hal ini dapat memberi pengaruh buruk bagi sistem hukum di Australia bahkan berpotensi menciptakan permasalahan dalam negeri yang dapat memicu sekelompok masyarakat tertentu merasa menjadi sasaran dari pemerintahnya sendiri (Cherney \& Murphy 2017). Keterlibatan institusi finansial juga menunjukkan tren serupa dimana masyarakat merasa seperti ditarget oleh pemerintahnya sendiri (Tham 2007).

Secara eksternal, kajian ini membahas kerangka-kerangka yang dijalankan oleh Australia dengan negara-negara sekitarnya melalui perjanjian bilateral. Dengan Filipina, kebutuhan untuk memperluas hubungan pertahanan dengan saling mengakui kepentingan strategis dalam keamanan regional pasca 9/11 menjadi sangat penting. Adapun komparasi historis dan psikologis dengan New Zealand dan Inggirs untuk menjelaskan perbedaan persepsi yang kemudian dibandingkan dengan pengalaman Australia (Battersby 2018), (Todd, Wilson \& Casey 2005).

Secara material kajian ini juga membahas kerangka kerja sama yang akan dilakukan oleh kedua pihak untuk memitigasi ancaman (Banlaoi 2003). Pada posisi yang sama, strategi komperhensif untuk keterlibatan secara regional, membutuhkan serangkaian kebijakan khusus yang lebih kuat untuk melawan ancaman terorisme Islam dengan sensitifitas yang ada di negara sekitar Australia. Hal ini kemungkinan akan menempatkan ketegangan yang lebih besar lagi pada kebijakan luar negeri dan keamanan Australia dalam interaksinya dengan negar-negara tetangga seperti Indonesia, Malaysia, hingga Filipina. Meskipun demikian, menemukan dan mencapai keseimbangan yang tepat akan sangat penting bagi Australia kepentingan nasional jangka panjang (Ungerer 2006). Oleh karenanya penting bagi Australia untuk menjalankan proyeksi kebijakan yang praktikal untuk memitigasi ancaman terorisme dengan melibatkan hubungan khusus dengan negara-negara di sekitar terutama di Asia Tenggara sebagai sumber ancaman ekstrimis Islam. Konteks ancaman non-tradisional di kawasan dan implikasi kepentingan strategis negara-negara menjadi hal yang sangat penting. Hal ini akan berpengaruh signifikan dalam inisiatif kontra-teroris me Australia.

Berdasarkan kajian terdahulu, yang paling jelas terlihat adalah tidak adanya pembahasan terkait bagaimana proses sekuritisasi pada isu terorisme di Australia. Kajian terdahulu lebih banyak membahas implikasi material dari proses sekuritisasi hingga dampak negatif dari produk sekuritisasi itu sendiri. Kajian ini akan mengisi kekosongan atas proses sekuritisasi yang dilakukan oleh Perdana Menteri Howard pada kasus terorisme terutama pasca 9/11. Pertanyaan inti yang berusaha dijelaskan dalam kajian ini adalah bagaimana proses speech act dalam kerangka sekuritisasi dilakukan oleh Perdana Menteri Howard dalam konteks memitigasi ancaman terorisme pasca 9/11. Kajian ini akan menggunakan pada kerangka analisa teori sekuritisasi. 


\section{Sekuritisasi Isu dan Metode Penelitian}

Sekuritisasi dalam perkembangannya merupakan langkah untuk melakukan tindakan politik yang berada di luar aturan permainan dengan membingkai masalah secara khusus. Sekuritisasi bahkan dilihat sebagai versi ekstrim dari sebuah politisasi isu yang memiliki tujuan politis (Buzan \& Weaver 2003). Sesuai dengan kerangkanya, struktur teori sekuritisasi menitikberatkan pada sebuah proses yang juga saling berimplikasi pada praktik keamanan. Teori sekuritisasi muncul dan berkembang dalam kerangka kajian keamanan dengan tujuan proses sekuritisasi untuk memperoleh status ancaman keamanan sehingga dapat melegitimasi tindakan di masa depan (Vuori 2008). Pada level negara, kajian keamanan menempatkan posisi keberlangsungan hidup negara sebagai alasan utama proses sekuritisasi dapat, bila tidak harus terjadi. Proses ini akan menghadirkan tindakan luar biasa (extraordinary measures) untuk memitigasi ancaman. Sekuritisasi diposisikan sebagai kombinasi proses aktual sekuritisasi dan praktek dari keamanan tersebut dengan kriteria-kriteria untuk evaluasi dari proses tersebut (Kurniawan 2018). Meskipun demikian, pada kajian proses evaluasi akan dibahas secara terpisah dari proses sebagai bentuk kontrol atas sebuah proses atau mekanisme sekuritisasi yang dilakukan pada tingkatan unit dan subsistem. Hal ini dilakukan untuk membatasi kajian agar naik atau turun pada tingkatan yang berbeda.

Dalam mempelajari sekuritisasi sebagai proses, prasyarat konsep atau komponen sekuritisasi yang harus ada antara lain; 1) existential threat, 2) referent object, 3) emergency situations, 4) extraordinary measures. Existential threat mengarah pada prioritas dari sebuah ancaman yang lebih tinggi dari ancaman-ancaman lain yang didasarkan atas dominasi isu yang dapat berimplikasi pada isu-isu lain sehingga ditempatkan pada posisi khusus yang penting (Kurniawan 2018). Referent object secara sederhana berupakan bagian-bagian yang secara langsung berhadapan dengan existential threat dan keberadaannya diancam oleh ancaman tersebut. Pada kondisi ini, objek ini dapat berupa eksistensi negara, kedaulatan nasional, ekonomi nasional, identitas kolektif, dan habitat lingkungan. Secara jelas, objek referensi dan jenis ancaman eksistensial dihadapi dapat bervariasi di berbagai sektor keamanan (Emmers 2003).

Justifikasi terhadap dua variabel konsep tersebut merupakan hal yang penting untuk kemudian dapat dilanjutkan kepada tahapan emergency situations dan extraordinary measures. Posisi emergency situations sebagai dasar dari diberlakukannya extraordinary measures. Hal ini atas landasan ancaman keamanan maksimal sehingga perlunya tindakan luar biasa untuk mencegah atau memitigasi ancaman. Kondisi ini secara politik tidak memiliki batasan apabila proses sekuritisasi dan justifikasinya berjalan (Kurniawan 2018). Selanjutnya, komponen yang paling utama dalam keberhasilan sebuah sekuritisasi ruang lingkup proses adalah speech act. Speech Act merupakan tindakan untuk mengartikulasi sebuah persoalan yang dikonsepsikan dalam sebuah kerangka keamanan. Tindakan ini dimaksudkan untuk mempengaruhi dan membujuk masyarakat atau audience untuk melihat kondisi ancaman. Artikulasi yang dilakukan oleh aktor sekuritisasi ini bertujuan khusus untuk mengkonstruksikan ancaman tersebut, sehingga memperoleh kewajiban dan legitimasi aktivasi kekuasaan negara untuk melakukan tindakan-tindakan luar biasa (extraordinary measures) yang melampaui aturan tradisional untuk memitigasi ancaman (Emmers 2016). Speech act dalam kajian ini merujuk pada karakterisasi "untuk mengatakan sesuatu" (locutionary act), "untuk bertindak dengan menyampaikan maksud" (illocutionary act), "untuk menghasilkan sesuatu dengan bertindak dengan menyampaikan sesuatu” (perlocutionary act) (Balzacq 2011).

Kajian ini akan menggunakan metode kualitatif untuk melacak proses speech act dengan mempertimbangkan sebab-akibat dengan menggunakan analisis empiris dalam-kasus 
yang terperinci tentang bagaimana proses kausal dimainkan dalam kasus yang sebenarnya . Kajian ini akan menggunakan data-data yang diperoleh melalui buku, jurnal maupun berbagai media massa yang diperoleh melalui media daring. Data-data yang digunakan akan diperoleh dalam rentang waktu sejak serangan terorisme pada 11 September 2001 hingga dukungan terhadap invasi Afghanistan beserta implikasinya pada legitimasi politik yang mendorong terpilihnya kembali Perdana Menteri Howard pada pemilu 2001 dan 2004.

\section{Speech Act oleh Perdana Menteri Howard tentang Ancaman Terorisme Global.}

Perdana Menteri Howard merupakan aktor sekuritisasi yang paling dominan pada proses sekuritisasi kontra-terorisme global di Australia. Perdana Menteri Australia menunjukkan sebuah tindakan speech act untuk menyampaikan sesuatu (locutionary act) melalui pidato-pidato yang disampaikan. Speech act cukup bergantung pada narasi bahasa yang digunakan untuk menciptakan sebuah figure, dan dilakukan secara kontinu, tidak selalu berlangsung dalam waktu lama, namun juga memanfaatkan intensi emosional dalam momen tertentu yang dikaitkan dengan nilai-nilai yang ditentang oleh tindakan terorisme. Inti dari tindakan speech act yang dilakukan oleh Perdana pada proses sekuritisasi adalah untuk mempromosikan prasyarat komponen sekurtisasi. Ketika serangan 9/11 terjadi, Perdana Menteri Australia sedang berada di Washington DC untuk membahas isu domestik keamanan Australia. Tepat ketika Perdana Menteri Howard sedang menyampaikan pidatonya tentang serangan di New York, serangan berikutnya terjadi di Pentagon. Dalam pidato yang kemudian dilanjutkan di Kedutaan Australia pada 11 September 2001, Perdana Menteri Howard kemudian menyampaikan komitmennya untuk mendukung penuh upaya Amerika Serikat untuk melakukan serangan balik bagi yang bertanggung jawab terhadap serangan "Pearl Harbour abad ke-20" ini (Anwy 2016). Penggunaan narasi "Pearl Harbour abad ke-20" berusaha untuk menekankan padabayangan traumatik terkait tragedi yang sebelumnya pernah terjadi. Sehingga dapat memunculkan ketakutan yang ada dalam diri audiens.

Selanjutnya, pada tanggal 14 September 2001, Perdana Menteri Howard bersama kabinet khusus mengajukan untuk aktifasi dari Pasal IV dari Security Treaty between Australia, New Zealand and the United States of America (ANZUS) untuk pertama kalinya sepanjang 50 tahun aliansi antara Amerika Serikat dan Australia telah berjalan. Hal ini sesuai dengan perjanjian dan petunjuk dari 'Application of ANZUS Treaty to Terrorist Attacks on United States' yang menunjukkan Pasal IV Perjanjian ANZUS menyatakan bahwa setiap anggota yang menyadari adanya serangan bersenjata di wilayah Pasifik yang akan berdampak bahaya bagi perdamaian dan keamanannya, maka anggota terkait dapat mendeklarasikan hal tersebut sebagai sebuah bahaya bersama yang sesuai dengan proses konstitusional (The ANZUS Treaty 1997). Dalam pidatonya, Perdana Menteri Howard juga menekankan bahwa potensi bahaya terorisme harus segera dimitigasi dengan tidak menunggu para teroris melakukan serangan lainnya.

Pengaktifan Pasal IV Perjanjian ANZUS dilakukan untuk menunjukkan dan mendemostrasikan komitmen tegas pemerintah Australia untuk terlibat langsung dalam agenda "Perang terhadap Terorisme" dan tindakan kontra-terorisme global yang diinisiasi oleh Presiden Amerika Serikat, George W. Bush. Pada titik ini, aktifasi dari Pasal IV membuka peluang untuk diterapkannya tindakan luar biasa (extraordinary measures) dalam memaknai serangan terorisme sebagai ancaman bagi keamanan Australia (existential threat), yang dalam jangka panjang mempengaruhi kepentingan nasional Australia (referent object) baik secara domestik maupun di luar negeri. Melalui hal ini, sebagai bentuk speech act. Pidato ini membuka jalan bagi proses speech act yang dilakukan Perdana Menteri Howard yang kemudian dilanjutkan oleh Pemerintah Federal Australia. Untuk menindaklanjuti hasil dari rapat kabinet 
khusus, Perdana Menteri Howard membutuhkan persetujuan dari Parlemen Australia untuk memperoleh legitimasi secara kelembagaan.

Dalam pernyataan yang ditujukan kepada Parlemen Australia pada 17 September 2001, dalam upaya sekuritisasi melalui speech act Perdana Menteri Howard menekankan kembali pentingnya posisi Australia untuk menjalankan fungsi aliansi yang ada pada Pasal IV Perjanjian ANZUS untuk membantu dan mendukung tindakan "Perang terhadap Terorisme" oleh Amerika Serikat dalam tindakan kontra-terorisme global. Sebagai bagian dari speech act, Perdana Menteri Howard menyampaikan pidato dengan memberikan hubungan relasional antara potensi ancaman dan ketidakpastian atas sektor keamanan yang mungkin dihadapi Australia apabila tindakan terorisme global dibiarkan berkembang dengan bebas. Hal ini disampaikan ketika kecemasan publik atas ancaman keamanan dari imigran gelap dan terorisme global sedang berada pada puncaknya (De Castella, et al. 2009). Pada pidato ini, speech act dilakukan dengan cara kapitalisasi ketakutan dan mempromosikan ketidakpastian nilai umat manusia secara umum dan keamanan Australia secara khusus. Hal tersebut juga didukung dengan gambaran tentang serangan 9/11 yang terjadi menggunakan unsur pembahasaan yang sangat buruk dengan menyebutkan pihak yang bertanggung sebagai "umat manusia yang tak bermoral" yang kemudian secara tematik menghubungkan tindakan terror yang dilakukan sebagai tindakan yang merenggut nilai-nilai fundamental dan kebebasan dari manusia oleh sekelompok manusia jahat radikal yang merencanakan tindakan jahat selama bertahun-tahun untuk mengacaukan peradaban manusia. Pada akhir pidatonya, Perdana Menteri Howard juga menunjukkan notasi emosional personal bagamana seorang istri, suami, atau anak-anak kehilangan orang yang mereka cintai dengan tiba-tiba, dan pentingnya negara untuk bersiap untuk menghadapi kemungkinan tersebut (De Castella, et al. 2009). Diskursi politik yang diupayakan oleh Perdana Menteri Howard melalui proses sekuritisasi ini melibatkan unsur framing bahwa serangan 9/11 sebagai sebuah serangan terhadap nilai-nilai bersama yang diadaptasi oleh Australia, sehingga keterlibatan Australia dalam dukungan serangan balasan pada pihak yang bertanggung jawab adalah sesuatu yang normal, bila tidak tak terhindarkan (Holland 2010). Hal ini menjadi kondisi yang istimewa dan khusus (extraordinary measures) karena hal tersebut tidak pernah sama sekali dilakukan sebelumnya dan dengan landasan hukum domestik tentang kontra-terorisme global yang belum ada hingga akhirnya disahkan pada 27 Mei 2002. Melalui debat parlemen ini, Parlemen Australia kemudian mendukung inisiatif Perdana Menteri Howard untuk mengaktifkan Pasal IV Perjanjian ANZUS. Legitimasi kelembagaan dari Parlemen Australia Perdana Menteri Howard untuk melakukan tindakan luar biasa atau khusus pada titik ini dapat terjadi. Berikutnya proses speech act harus mencapai tingkat audiens masyarakat. Pada proses ini, sekuritisasi dalam ruang lingkup speech act juga dilakukan dengan bantuan media televisi. Salah satu saluran berita televisi Channel 10 menyiarkan kejadian yang terjadi di Amerika Serikat sebagai dampak dari serangan 9/11. Seluruh program malam selain berita siaran langsung pada 17 September 2001 dibatalkan, sehingga sepanjang malam masyarakat menyaksikan kejadian yang berkaitan dengan serangan 9/11 (Anwy 2016).

Sebagai bagian dari tindak lanjut dari persetujuan Parlemen Australia atas dukungan kepada aktifasi Pasal IV Perjanjian ANZUS, persiapan militer termasuk Pasukan Operasi Khusus untuk membantu Amerika Serikat. Akhirnya, pada 7 Oktober 2001, pasukan gabungan dibawah komando Amerika Serikat melakukan serangan terhadap kelompok Taliban di Afghanistan (Anwy 2016). Dua ratus personel Pasukan Operasi Khusus Australia di bawah Operasi Slippers dikirim bersama dengan Pasukan Angkatan Darat, Laut dan Udara dikirim secara berkala pada 22 Oktober 2001. Pada 25 Oktober 2001, Resimen ke-16 Pertahanan Udara dikirim untuk membantu Pasukan Maritim untuk berperang melawan teroris. Hingga tahun 2014, total personel militer Australia yang ada di Afghanistan mencapai 26.000 orang. Bahkan keterlibatan militer Australia di Afghanistan merupakan perang terlama militer Australia dalam 
sejarah (Brangwin 2010). Meskipun tindakan tersebut sudah dijalankan, speech act tetap dilanjutkan sebagai upaya untuk memperkuat legitimasi. Menteri Pertahanan Australia kerap menyampaikan tujuan fundamental Australia di Afghanistan adalah untuk menghapuskan ancaman terorisme internasional untuk kepentingan keamanan internasional dan kepentingan domestic Australia untuk terbebas dari ancaman terorisme (Australian Army in Afghanistan).

\section{Politik Keamanan Perdana Menteri Howard}

Speech act berjalan pada spektrum yang senada dengan diskursus politik dimana politis $\mathrm{i}$ melakukan sebuah tindakan luar negeri maupun kebijakan secara umum atas pertimbangan untuk membentuk permaknaan dan identitas politik yang lebih kuat. Hal ini yang menyebabkan proses sekuritisasi pada batas tertentu dianggap sebagai politisasi isu dalam tingkatan ekstrim.

Pada kasus sekuritisasi kontra-terorisme global dalam bentuk dukungan invasi militer ke Afghanistan, Holland (2010) menyebutkan bahwa diskursus politik luar negeri yang dilakukan oleh Perdana Menteri Howard pada "Perang terhadap Terorisme" dengan memberikan dukungan militer ke Afghanistan tidak tersingkronisasi dengan baik, dan cukup berbeda dengan kepentingan strategis dari negara-negara pendukung yang lain. Namun demikian, kalkulasi rasional yang dimainkan oleh Perdana Menteri Howard pada diskursus politik ini didasarkan oleh politik kekuasaan (Holland 2010).

Kombinasi diskursus politik yang dibarengi oleh speech act tersebut membuat proses sekuritisasi ini berhasil terjadi. Bahkan, Perdana Menteri Howard berhasil meyakinkan lawan politiknya Kim Beazley untuk melakukan tindakan yang khusus yang diperlukan dengan tidak banyak melakukan perlawanan politik terhadap isu terorisme yang dimainkan oleh Perdana Menteri Howard. Terlebih, yang paling menunjukkan signifikansi dari keberhasilan speech act Perdana Menteri Howard adalah kemampuan untuk mengkapitalisasi agenda keamanan nasional menjadi sebuah kekuatan politik dalam negeri. Perdana Menteri Howard awalnya memulai tahun 2001 dengan citra polling yang buruk sejak berkurangnya kepercayaan pengusaha dan nilai tukar. Namun demikian, Perdana Menteri Howard mampu memainkan babak akhir pemilihan umum dengan adanya isu internasional yang dikaitankan dengan nuansa ancaman nasional Australia, yang mana dalam catatan sejarah memberikan keuntungan bagi petahana atau kepala pemerintahan (McAllister 203). Proses sekuritisasi juga sangat didukung dengan adanya momentum dan bantuan dari media untuk mendorong proses sekuritisasi terutama dalam tahapan speech act. Peran media Australia saat itu sangat mempengaruhi masyarakat dalam menyatakan pilihan politik, terutama mereka yang memiliki kepentingan politik dan kesadaran politik atas adanya isu internasional. Pada akhirnya, pilihan politik tersebut diberikan pada aktor politik sekaligus aktor sekuritisasi yang mendukung terjadinya proses sekuritisasi isu terorisme global pasca 2001 (Denemark 2005).

Gambaran atas pergeseran suara pemilih pada pemilu 2001 berjalan sebagai berikut: 


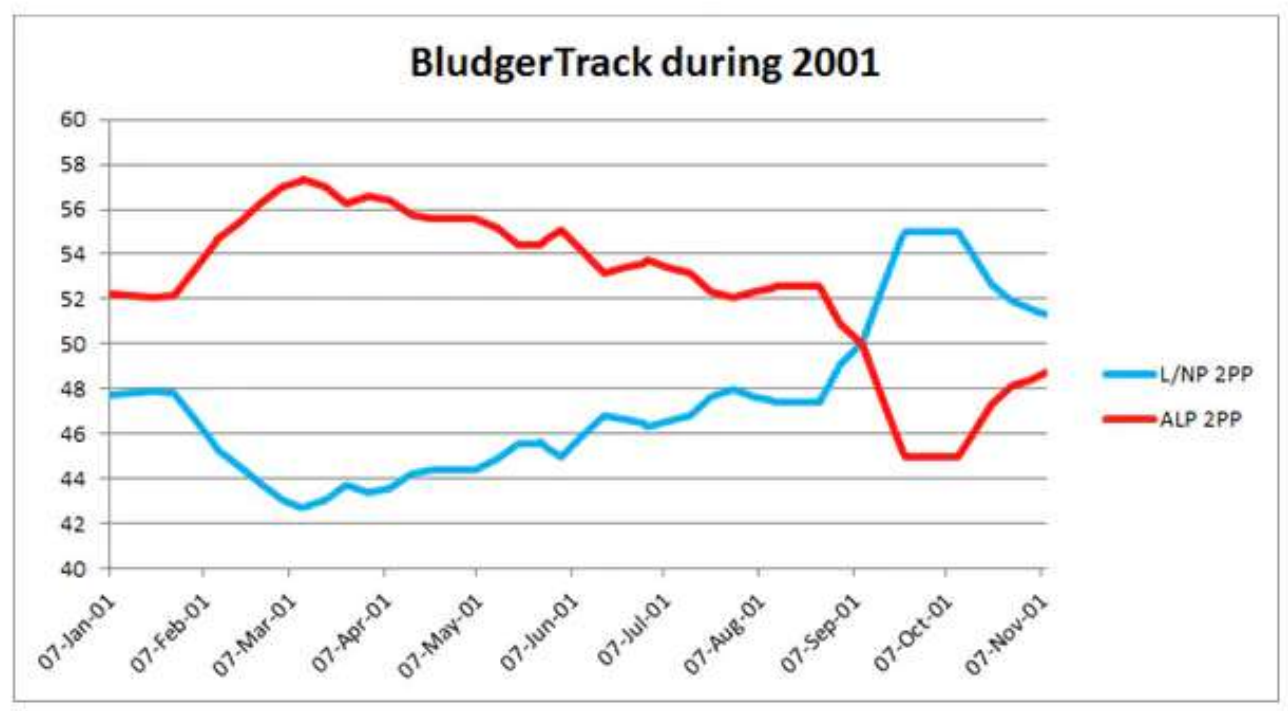

BludgerTrack two party preferred vote during 2001

Mendekati masa-masa pemilihan, Howard mulai mendominasi kampanye politik dengan memanfaatkan isu terorisme. Sejak minggu awal serangan 9/11, koalisi pemerintah mulai menguasai polling meningkat hingga mencapai puncak $55 \%$ melawan $45 \%$. Pada pemilu November 2001, Perdana Menteri Howard kembali menjabat sebagai Perdana Menteri Australia dengan suara populer (popular vote) 5.846.289 suara terpaut tipis dari lawannya Kim Beazly dengan suara populer (popular vote) 5.627 .785 suara. Selain itu koalisi pemerintah memperoleh 82 kursi dan oposisi menempati 65 kursi (Newman 2002). Hal ini menunjukkan legitimasi yang kuat diberikan oleh pemilih sebagai perwakilan dari rakyat yang mengapresia si tindakan Perdana Menteri Howard pada ruang lingkup sekuritisasi "Perang terhadap Terorisme" yang diwujudkan dengan aktifasi Pasal IV Perjanjian ANZUS sebagai tindakan luar biasa atau extraordinary measures.

\section{Penutup}

Kajian ini menunjukkan keberhasilan dari proses sekuritisasi yang dilakukan melalui speech act oleh aktor dominan dalam pemerintah Australia, dalam hal ini Perdana Menteri Howard pasca serangan teroris 9/11. Speech act yang dilakukan oleh Perdana Menteri Howard memperlihatkan kapitalisasi ketakutan yang efektif membangun kesadaran kolektif atas adanya existential threat yang diarahkan pada referent object dengan intensitas yang tinggi, meskipun pada saat itu Australia bukanlah korban utama dari serangan terorisme global. Keberhasilan dari proses sekuritisasi ini kemudian memberikan legitimasi politik yang pada akhirnya dapat dimanfaatkan untuk mengembangkan politik kekuasaan, terlepas target utama dari sekuritisasi tersebut melibatkan tujuan ini atau tidak pada mulanya.

Argumentasi dari kajian ini yang melihat langkah speech act dalam ruang lingkup proses sekuritisasi yang dilakukan Perdana Menteri Howard yang dimulai dari komunitas internasional dalam pidato terbuka. Berikutnya, ketakutan yang muncul sebagai dampak serangan terorisme diarahkan pada kabinet khusus untuk menekan Parlemen Australia agar setuju pada inisiatif yang diajukan. Selanjutnya, kapitalisasi dari speech act tersebut juga membuat legitimasi dari diberlakukannya tindakan luar biasa dalam bentuk dukungan militer terhadap invasi ke Afghanistan. Hasil akhir dalam spektrum tersebut menjadikan legitimasi politik dari Perdana Menteri Howard untuk terpilih kembali sebagai Perdana Menteri Australia pada pemilu 2001. 


\section{Daftar Pustaka}

\section{Buku}

Balzacq, Thierry. 2011. Securitization Theory: How Security Problems Emerge and Dissolve. New York: Routledge.

Brangwin, N. 2010. Australia's Military Involvement in Afghanistan since 2001: a Chronology. Canberra: Department of Parliamentary Library.

Buzan \& Weaver. 2003. Regions and Power: The Structure of International Politics. New Yok: Cambridge University Press.

Newman, G. 2002. Federal Election Result 1949-2001. Canberra: Department of Parliamentary Library.

Kurniawan, Y. 2018. The Politics of Securitization in Democratic Indonesia. Springer International Publishing.

Emmers, R. 2016. Securitization In Contemporary Security Studies, by A Collins. Oxford university press.

Anwy, B. 2016. John Howard's Australia and September 11. Victoria University Press.

\section{Jurnal Artikel}

Banlaoi, R. 2003. "Broadening Philippine-Australia Defence Relations in the Post 911 Era: Issues and Prospects. ." Contemporary Southeast Asia, 25(3) 473-488.

Battersby, J. 2018. "Terrorism Where Terror Is Not: Australian and New Zealand Terrorism Compared." Studies in Conflict \& Terrorism, 41(1) 59-76.

Chau, A. 2008. "Security Community and Southeast Asia; Australia, the US and ASEAN's Counter-Terrorism Strategy." Asian Survey 48(4) 626-649.

Cherney \& Murphy. 2017. "Police and Community Cooperation in Counterterrorism: Evidence and Insight from Australia." Studies in Conflict and Terrorism 40:12 10231037.

Crowley \& Larsen. 2015. "Government as usual: politics and law as structural couples governing counter-terrorism in Australia." Griffith Law Review, 24(4) 519-547.

De Castella, et al. 2009. "Fear Appeals in Political Rhetoric about Terrorism: An Analysis of Speeches by Australian Prime Minister Howard." Political Psychology, Vol. 30, No. 1.

Denemark, D. 2005. "Information Flow and Voter Decision Making in the 2001 Australian Federal Election: The Role of International and Domestic Issues." Political Research Quarterly 58:3 397-412.

Emmers, R. 2003. "ASEAN and The Securitization of Transnational Crime in South East Asia." The Pacific Review16:3 419-438.

Holland, J. 2010. "Howard's War on Terror: A Concievable, Communicable and Coercive Foregin Policy Discourse." Australian Journal of Political Science, 45:4 663-661.

Lyon, R. 2003. "Australia's security and the threat of Islamic extremism in southeast Asia. ." Cambridge Review of International Affairs, 16(3) 447-462.

McAllister, Ian. 203. "Border Protection, 2001 the Australian Election and Coalition Victory." Australian Journal of Political Science, 38:3 445-463.

Michaelsen, Christopher. 2006. "Antiterrorism Legislation in Australia: A Proportionate Response to the Terrorist Threat?" Studies in Conflict \& Terrorism, 28(4) 321-339.

Tham, J. 2007. "A Risk-Based Analysis of Australia's Counterterrorism Financing Regime." Social Justice 32(4) 138-152. 
Todd, Wilson \& Casey . 2005. "Comparing British and Australian Fear of Terrorism Pre and Post Iraqi War." Psychology and Law, 12(1) 184-193.

Ungerer, C. 2006. "Australia's policy responses to terrorism in Southeast Asia." Global Change, Peace \& Security, 18(3), 193-199.

Vaughn, B. R. 2004. " Australia's strategic identity post-september 11 in context: Implications for the war against terror in southeast asia." Contemporary Southeast Asia, 26(1) 94115.

Vuori, J A. 2008. "Illocutionary Logic and Strands of Securitization: Applying the Theory of Securitization to the study of Non-Democratic Political Orders." European Journal of International Relations, 14(1) 65-99.

\section{Website dan Laporan}

ASIO Report to Parliament 2001-2002. Australia Security Intelligence Organisation. Diakses pada 20 Mei 2018

www.asio.gov.au/sites/default/files/ASIO\%20Report\%20to\%20Parliament\%202001-02.pdf

Australian Defence Force in Afghanistan. Parliament of Australia. Diakses pada 22 Mei 2018 www.aph.gov.au/About_Parliament/Parliamentary_Departments/Parliamentary_Library/pubs/ BriefingBook43p/adfafghanistan

The ANZUS Treaty. 1997. Department of External Affairs. Diakses pada 24 Mei 2018 melalui www.aph.gov.au/ /media/wopapub/house/committee/jfadt/usrelations/report/appendixb_pdf.a $\operatorname{shx}$ 